\title{
Interactions between sediment-feeders and microalgae on coral reefs: grazing losses versus production enhancement
}

\author{
Sven Uthicke* \\ Institut für Hydrobiologie und Fischereiwissenschaft, Zeiseweg 9, 22959 Hamburg, Germany
}

\begin{abstract}
The close coupling between producers and consumers of inorganic nutrients is generally assumed to be important to maintaining high productivity on coral reefs. I examined whether a tight cycling of nutrients exists between benthic microalgae and sediment-feeding holothurians (Stichopus chloronotus and Holothuria atra). Benthic microalgae had an increased production (measured as $\mathrm{O}_{2}$ evolution) after exposure for more than $3 \mathrm{~h}$ to effluent water from tanks containing holothurians. Direct addition of phosphate and ammonium suggested that this increase was mainly caused by the excretion of ammonium. In experiments in which a part of the sediment area was inaccessible to the holothurians, microalgae production significantly increased in aquaria containing holothurians, irrespective of whether microalgae were grazed or protected from grazing. Thus, it could be inferred that production enhancement is solely a nutrient effect and not due to other effects described for other grazers (e.g. removal of senescent cells or reduction of self-shading). The effects on the microalgal biomass (measured as chlorophyll $a$ and phaeophytin) depended on the actual grazing intensity. When a high grazing pressure was simulated (e.g. 2 H. atra on $0.116 \mathrm{~m}^{2}$ ), microalgal biomass was reduced significantly after $7 \mathrm{~d}$ compared to control aquaria. At lower grazing intensities (e.g. $1 \mathrm{~S}$. chloronotus on $0.232 \mathrm{~m}^{2}$ ), the microalgal biomass increased significantly. A significant negative correlation was found between the amount of sediment consumed in each single aquarium (measured as the weight of the faeces produced) and the increase in chlorophyll $a$ and phaeophytin concentrations in the sediment. A comparison with in situ sediment-consumption rates suggested that holothurians in natural densities have an overall beneficial effect on the benthic microalgal community. I propose that holothurians and other sediment-feeders are important components of a benthic recycling system that may have some similarity to the planktonic microbial loop.
\end{abstract}

KEY WORDS: Productivity $\cdot$ Sediment-feeders $\cdot$ Microalgae $\cdot$ Holothurians $\cdot$ Grazing $\cdot$ Recycling Close coupling Resale or republication not permitted without written consent of the publisher

\section{INTRODUCTION}

Coral reefs are regarded as one of the most productive marine ecosystems in terms of gross productivity (Sorokin 1990). Although 20 to $30 \%$ of the primary production on coral reefs is accomplished by benthic

\footnotetext{
*Present address: Australian Institute of Marine Science, PMB No 3, Townsville, Queensland 4810, Australia.

E-mail: suthicke@aims.gov.au
}

microalgal communities on soft sediments (Sorokin 1993), and up to $40 \%$ of the Great Barrier Reef (GBR) is a suitable habitat for these communities (Uthicke \& Klumpp 1998), information on their ecology is sparse.

The trophic flow through grazing pathways is more important on coral reefs than in temperate shallowwater ecosystems (Hatcher 1983). However, several studies have indicated that often more than $50 \%$ of the primary production on coral reef systems is channelled through detritus-based food chains (Crossland et al. 
1984, Johnson et al. 1995, Arias-Gonzáles et al. 1997). The level of herbivory is high on coral reefs compared to other benthic systems and a large proportion of benthic primary productivity may be directly consumed by herbivores (Carpenter 1986, Klumpp \& Polunin 1990). The interaction between herbivore activity and watercolumn nutrient concentrations has been suggested as the primary factor structuring coral reef communities: a high coral cover is predicted only in low nutrient concentrations in combination with high herbivore activity (the 'relative dominance model'; Littler \& Littler 1984).

In aquatic sciences, the term 'grazing' is often used as a synonym for herbivory to describe the consumption of primary producers, but consumption of bacteria is also often termed grazing (e.g. Montagna 1984, Moriarty et al. 1985, Hansen \& Skilleter 1994). The effects that grazers have on plant production are composed of negative feedback effects by consumption, and of a variety of potential positive feedback effects. In the case where the positive feedback exceeds the negative effects, the overall production of the plants is stimulated (Mitchell \& Wass 1996). The positive feedback effects of grazers have been relatively well studied in freshwater environments. The nutrient excretion by lake zooplankton increases the production of several phytoplankton species (Porter 1976, Sterner 1986), and the grazing activity of benthic invertebrates may enhance the availability of nutrients in streams through enhanced nutrient turnover ('nutrient spiralling'; Newbold et al. 1982, Mulholland et al. 1991). In marine plankton, nutrient regeneration rates by grazing zooplankton are often sufficient to satisfy the nutrient demand of phytoplankton (e.g. Glibert et al. 1988, Miller et al. 1995). A large fraction of the regenerated nutrients is derived from the microzooplankton (Miller et al. 1995), which highlights that flagellates and ciliates in the 'microbial loop' (Azam et al. 1983, Lenz 1992) are important in the efficient recycling of nutrients.

An efficient nutrient recycling by a close coupling between producers and consumers has also been suggested for coral reefs, which usually occur in nutrientpoor environments (Atkinson 1989); however, very few studies have investigated feedback effects of grazers in these ecosystems. D'Elia \& Wiebe (1990) recognised this problem and stated that a 'grazing regeneration pathway' may be important to promote high primary production on coral reefs, and that information on this pathway is virtually non-existent. Exceptions are studies on the grazing by the echinoid Diadema antillarum, which was estimated to supply a significant amount of the $\mathrm{N}$ demand of algal turf by ammonium excretion (Williams \& Carpenter 1988). Turf algae grazed by $D$. antillarum may have a higher biomass-specific productivity than ungrazed algae or those grazed by fishes
(Carpenter 1986). The latter author concluded that grazing on coral reefs may be analogous to terrestrial grazing on grasslands and savannas. In these areas, the production of grazed plants is often higher than the production of plants experimentally protected from grazing by ungulates; this has been attributed to the removal of senescent tissue, decrease in self shading, the induction of compensatory plant growth, and/or the re-mineralisation of plant nutrients by grazers (McNaughton 1979, 1983, see also Milchunas \& Lauenroth 1993).

More information exists on the negative, or direct, effects of herbivory by coral reef organisms on plant communities. Herbivory by fishes and echinoids may be an important top-down control mechanism of algal biomass in coral reef systems (Hatcher 1983, Hatcher \& Larkum 1983, Hay 1984, Hughes 1994). Grazing by amphipods may influence species composition and biomass of reef algae (Brawley \& Adey 1981). In coral reef sediments, the number of bacteria was reduced by the grazing activity of a gastropod (Hansen \& Skilleter 1994).

In the present study, I investigated the interaction between sediment-feeders and benthic microalgae on coral reefs. Aspidochirotide holothurians provide suitable model organisms for the study of feeding and nutrient recycling of sediment-feeders in coral reef ecosystems because they often occur in high densities and biomass on the reef flat and backreef, and consume significant amounts of sediment (Uthicke 1999). The main food sources of aspidochirotide holothurians are bacteria, microalgae and dead organic matter of plant and animal origin (Yingst 1976, Massin 1982, Moriarty 1982).

The production and biomass of benthic microalgae were reduced by the grazing activity of holothurians in high experimental densities (Moriarty et al. 1985, Uthicke 1999). In contrast, it has been shown in aquaria experiments (Uthicke \& Klumpp 1997) and in situ (Uthicke \& Klumpp 1998) that microalgal production was enhanced when the algae were subjected to water which had passed holothurians. The latter authors suggested that this was caused by increased availability of ammonium.

As for most marine invertebrates, the main excretion products of holothurians are ammonium and small amounts of phosphate (Pomeroy \& Kuenzler 1969, Webb et al. 1977, Mukai et al. 1989). These nutrients originate from the digestion and re-mineralisation of various organic compounds in the sediment. The pool of $\mathrm{P}$ and $\mathrm{N}$ in the sediments of coral reefs is usually high (Entsch et al. 1983, Furnas et al. 1995) compared to the oligotrophic waters surrounding most coral reefs. The recycling of these nutrients by benthic grazers is assumed to be important to maintain the high productivity on coral reefs (D'Elia \& Wiebe 1990). 
The aim of the work described here is to investigate the hypotheses that (1) the previously described enhancement of microalgal production by the presence of holothurians is caused by a short-term elevation in the availability of ammonium, and that (2) the sum of the negative effects caused by consumption of microalgae and the positive effects through nutrient regeneration by sediment-feeders equals zero or is positive. This has been achieved by a series of experiments and comparison of the results with known bioturbation rates from the field.

\section{METHODS}

General analytical methods. Chemical methods: Water samples for nutrient analyses were collected by syringe and were immediately filtered through acidwashed and precombusted glass-fibre filters (Whatman, pore size $0.45 \mu \mathrm{m}$ ) and stored at $-20^{\circ} \mathrm{C}$ until analyses. Nitrate and nitrite were analysed using standard automated techniques (Ryle et al. 1981). Samples for determination of dissolved organic phosphorus (DOP) and dissolved organic nitrogen (DON) were photo-oxidised in ultraviolet light for $8 \mathrm{~h}$ to convert organic into inorganic nutrient species, and subsequently analysed for nitrate and nitrite. Ammonium and phosphate concentrations were determined spectrophotometrically after Koroleff $(1983 a, b)$ with adaptations to a $10 \mathrm{ml}$ sample volume.

Chlorophyll $a$ and phaeophytin contents of the sediment were analysed as described in Uthicke \& Klumpp (1998).

Production measurements: Benthic community production and respiration were measured as variations in oxygen concentrations with a 4-chamber, data-logging respirometer described in Klumpp et al. (1987). Measurements for the experiments were performed in an indoor aquarium room. The production-irradiance curves of benthic communities in aquarium sediments in petri dishes showed light-saturation points between 200 and $300 \mu \mathrm{E} \mathrm{m}^{-2} \mathrm{~s}^{-1}$ (Uthicke \& Klumpp 1997). Therefore, I chose to measure production at a light intensity of $250 \mu \mathrm{E} \mathrm{m} \mathrm{m}^{-2} \mathrm{~s}^{-1}$, provided by halogen-floodlight (Osram Halostar $500 \mathrm{~W}$ ). Initial trials with control chambers containing no sediments showed no measurable production or respiration of phytoplankton in the water column of the aquaria water, thus it was not necessary to use filtered seawater. Water temperature during the production measurements and experiments varied between 27 and $29^{\circ} \mathrm{C}$. The water inside the incubation chambers was flushed every $15 \mathrm{~min}$. Oxygen concentration was recorded every minute for three $15 \mathrm{~min}$ intervals each in the light and in the dark. Production and respiration were calculated by linear regression of the oxygen concentration values over time. Sedi- ment area-specific rates are presented as gross production (adding light values and dark respiration rates) of oxygen $\mathrm{cm}^{-2} \mathrm{~min}^{-1}$.

Effect of nutrient enhancement and holothurian grazing on sediment microflora. Cultivation of benthic microalgae for aquarium experiments: Sediment was collected at Great Palm Island $\left(18^{\circ} 41^{\prime} \mathrm{S}, 146^{\circ} 35^{\prime} \mathrm{E}\right)$ in the central section of the GBR, and transported to the Australian Institute of Marine Science (AIMS) outdoor aquarium facility. The bulk sediment was kept in large tanks (1000 l) with a constant flow of natural seawater. At the start of each experiment, approximately $2 \mathrm{~kg}$ of sediment was transferred to polycarbonate containers $(29.8 \times 39.9 \times 20 \mathrm{~cm})$ to create a sediment layer of $1 \mathrm{~cm}$. The water outflow was $9.5 \mathrm{~cm}$ above the sediment surface. Sediments were left to recover their microalgal community for 7 to $10 \mathrm{~d}$. Sediments were not artificially incubated with benthic microalgae, because microscopic examination showed that after $7 \mathrm{~d}$ of pre-cultivation the microflora appeared similar to that in the field. Sediments in the field and the experiments were dominated by pennate diatoms $\left(\sim 1-5 \times 10^{6}\right.$ cells $\mathrm{ml}^{-1}$, Uthicke unpubl. data), with much lower numbers of cyanophytes, dinoflagellates and chlorophytes (Uthicke \& Klumpp 1997).

In experiments where production measurements were undertaken, plastic petri dishes (diam. $8.7 \mathrm{~cm}$ ) were filled with sediments and embedded to the level of the sediment surface. For measurements, these sedimentfilled petri dishes were covered with a lid to remove them from the surrounding sediments with minor disturbance to the algal community. For each set of measurements, 4 dishes were chosen randomly from the treatments of the respective experiment and inserted in the respirometer chambers after carefully removing the lids.

Study animals: All experiments were conducted with the aspidochirotide holothurian species Stichopus chloronotus (Brandt, 1835) and Holothuria (Halodeima) atra (Jäger, 1833). These holothurians are the most common species in the GBR; they occur in densities of up to $1.7 \mathrm{~m}^{-2}$ and their biomass may reach $240 \mathrm{~g} \mathrm{~m}^{-2}$ (wet wt) on GBR reefs (Uthicke 1994, Uthicke unpubl. data). Individuals for experiments were collected at Great Palm Island (in the same area as the sediments) and kept in large tanks at AIMS. In grazing experiments, specimens of $S$. chloronotus were used to simulate low grazing pressure and of $H$. atra to simulate high grazing pressure. These a priori assumptions were based on my previous experience with the feeding of these animals in captivity (Uthicke 1999). However, estimates for the 'real' bioturbation activity in each experimental unit were obtained and used in the final regression analysis (see end of 'Methods' section). 
Expt A-effect of exposure time: Three experiments were conducted to determine the influence of exposure time with elevated nutrient concentrations on microalgal production. Microalgae in the sediments were pre-cultivated for $8 \mathrm{~d}$ in petri dishes as described above. For each trial, 3 treatment aquaria that received effluent water from tanks containing 4 specimens of each Stichopus chloronotus and Holothuria atra and 3 control aquaria that received untreated aquarium water were installed on an aquarium bench in the outdoor aquarium system. For Expt A1 (1.5, 3 and $4.5 \mathrm{~h}$ exposure) and Expt A2 (6, 12, 18 and $24 \mathrm{~h}$ exposure), the petri dishes were placed for exactly the exposure time into the treatment or control aquaria prior to measurements. After the exposure time, production of microalgae was measured in 10 control and 10 treatment dishes for each exposure period. In Expt A3 (0, 1, 2, 3 and $4 \mathrm{~d}$ ), all petri dishes were placed into the treatment and control aquaria at the beginning of the experiment; 9 replicate measurements were performed for the control and the treatments in this experiment. Measurements for Day 0 were started immediately after the experiment commenced, and the measurements for Days 1 to 4 were performed on the respective days. Since it took approximately $12 \mathrm{~h}$ to measure each 9 control and 9 treatment dishes, samples from Day 0 were actually exposed from 0 to $12 \mathrm{~h}$, for Day 1 from 22 to $34 \mathrm{~h}$, for Day 2 from 46 to $58 \mathrm{~h}$, for Day 3 from 72 to $84 \mathrm{~h}$, and for Day 4 from 96 to $108 \mathrm{~h}$. Nutrient samples for ammonium determination were taken from treatment and control aquaria and from the respective inflowing water in Expts A1 and A2. Similar samples from Expt A3 were analysed for all nutrient species listed earlier in the subsection 'Chemical methods'.

Expt B-enhancement with direct addition of phosphate and ammonium: To test whether potential enhancement of the microbenthos production was the result of holothurian excretion of the examined macronutrients and not of an elevated concentration of some unknown micro-nutrient(s), I conducted an experiment with direct addition of phosphate and ammonium. Forty sediment-filled petri dishes were prepared as described above and the microflora in the sediments was pre-cultivated for $7 \mathrm{~d}$ in 8 glass aquaria $(28.3 \times 41.8 \times$ $25 \mathrm{~cm}$ ) with flowing seawater and aeration in the outdoor aquarium. To control for tank effects, 2 of these aquaria were assigned randomly to each of 4 treatments. The water in each aquarium was changed 6 times $\mathrm{d}^{-1}$; on each occasion, the sediment algae in the treatment aquaria were fertilised with a nutrient pulse. The treatments were only $\mathrm{P}$-addition, only $\mathrm{N}$-addition, $\mathrm{N}+\mathrm{P}$ addition, and controls with no nutrients added. The phosphate treatment received $2.5 \mathrm{ml}$ of $2 \mathrm{mM}$ $\mathrm{NaH}_{2} \mathrm{PO}_{4}$ at each pulse, leading to a phosphate pulse of $0.17 \mu \mathrm{M}$. I added $2.5 \mathrm{ml}$ of $20 \mathrm{mM} \mathrm{NH}_{4} \mathrm{Cl}$ to the nitrogen treatments to achieve an approximate enhancement of $1.7 \mu \mathrm{M}$ ammonium. The $\mathrm{N}+\mathrm{P}$ treatment aquaria received the same amount of nutrients, with both ammonium and phosphate added. These treatments were applied 12 times over $48 \mathrm{~h}$. Thereafter, the production and respiration of the sediment community of each petri dish were measured. Water samples from all aquaria for ammonium and phosphate analyses were taken in duplicate on 4 occasions after a nutrient pulse.

Expt $\boldsymbol{C}$-production and biomass of grazed and ungrazed microalgae: Expts A and B tested the potential positive effect of nutrient elevation on microalgal biomass and production. To investigate the combined effects of grazing and nutrient excretion on microalgae, an experiment was designed that separated aquaria in grazed and ungrazed sides. For logistic reasons this experiment was performed in 2 experimental runs within 1 mo. In each run, 6 polycarbonate aquaria were filled with sediments and 6 sediment-filled petri dishes were placed into each aquarium, and microalgae were pre-cultivated as described above. At the start of the experimental runs, each aquarium was divided with a plastic mesh $(0.7 \mathrm{~cm}$ mesh size) into 2 equal-sized areas, and holothurians were placed only in one half (the 'grazed' side). The water flow was adjusted to $800-1000 \mathrm{ml} \mathrm{min}^{-1}$ for each aquarium. In each experimental run, 2 aquaria contained 2 individuals of Stichopus chloronotus, and 2 other aquaria 2 individuals of Holothuria atra. The 2 remaining aquaria were left empty as controls. Treatments were assigned randomly to the aquaria. Four samples for determination of chlorophyll $a$ and phaeophytin were taken from the sediment surface of each grazed and each ungrazed side of the aquaria at the start and the end (after $7 \mathrm{~d}$ ) of each experimental run. Similarly, the microbenthos community production in each petri dish was determined at the start and the end of the experimental runs. Ammonium concentrations in the water of each aquarium were measured twice during each run with duplicate samples.

Expt D-time-course of microalgal biomass changes under grazed and ungrazed conditions: To investigate the biomass development of grazed and ungrazed microalgal communities over time, an experiment was conducted using a similar setup as in Expt C. In Expt D, the grazing intensity was reduced, however, because 2 holothurians had access to sediments in the whole aquarium area. The ungrazed microalgae were located in an aquarium placed next to each aquarium containing the grazed microalgae. Aquaria with grazed microalgae were elevated on bricks to allow passive flow of effluent water (800 to $1000 \mathrm{ml} \mathrm{min}^{-1}$ ) via a connection tube to the aquaria with ungrazed microalgae. Six of these aquarium pairs were installed in the outdoor aquarium, each 
was filled with $2 \mathrm{~kg}$ of sediment and the microflora in these was pre-cultivated for $7 \mathrm{~d}$. At the start of the experiment, 2 individuals of Stichopus chloronotus were placed into 2 aquaria, and 2 Holothuria atra into each of 2 other aquaria, 2 aquaria were left without holothurians as controls. Three samples for pigment analyses were taken from the sediment surface from each aquarium over 6 consecutive days. Water samples for ammonium determination were collected in duplicate on 4 occasions from each aquarium and the ambient seawater.

Expt E-additional experiments on algal biomass changes: To gain further information on the impact of holothurian feeding activity on changes in biomass of microalgae, 3 further experiments were conducted subjecting sediment areas of different sizes (whole aquaria or divided aquaria) to 1 or 2 individuals of Stichopus chloronotus or Holothuria atra. Experiments were run in 6 to 12 aquaria, and sediment surface samples (4 replicates) were taken at the beginning and the end ( 6 to $8 \mathrm{~d}$ after the start) of the experiments for pigment analyses. Two control aquaria were included in each experiment to obtain an estimate for changes in microalgal biomass which occurred when no holothurians were present.

Statistical analyses and mathematical procedures. All statistical analyses were performed with the Statistica 4.5 (Statsoft 1994) programme package. Differences in microbenthos community production in the 4 treatments of Expt B were tested by 1-factor ANOVA.

Pigment concentrations and production rates in the sediments of Expt $\mathrm{C}$ were averaged over each grazed and ungrazed side of the aquaria, and the difference between the end and the start (= increase in pigment concentrations or production rates) was used as the dependent variable. The data were subjected to a 4factor ANOVA, with the experimental factors 'treatment' (3-levels: Stichopus chloronotus, Holothuria atra, control), 'aquarium' (2 replicate aquaria, nested in 'treatment'), 'grazed' (2 levels: grazed and ungrazed) and 'run' (first and second run). Preliminary analyses showed that the terms grazing $\times$ aquarium nested in treatment and run $\times$ aquarium nested in treatment were not significant for both pigments or production data as dependent variables. These terms were consequently pooled into the residual and used as an error term for all factors with the exception of treatment. The significance of the latter factor was tested using aquarium nested in treatment as the error term.

Time courses of the changes in chlorophyll $a$ and phaeophytin concentrations (Expt D) were analysed with a repeated-measures ANOVA, taking the concentrations at the single days as repeated measurements. Treatment (3-levels: Stichopus chloronotus, Holothuria atra, control), grazed (2 levels: grazed and ungrazed) were taken as fixed factors, with the factor aquarium nested in treatment.

Before subjection to ANOVAs, data were checked for homogeneity of variances with Cochran's $C$-test and, if necessary, transformed as indicated in 'Results'.

Pigment concentrations (chlorophyll $a$ and phaeophytin and the sum of both) from Grazing Expts C, D and $\mathrm{E}$ were subjected to an overall regression analysis. Therefore, the average pigment concentrations were calculated for each aquarium at the start and the end of each experiment. To obtain comparable units, the initial concentration was subtracted from the final concentration and divided by the duration of the respective experiment. The respective average value of the controls used in each experiment was subtracted from the average daily value for each aquarium containing holothurians to account for changes occurring independent of holothurian activity. This resulted in an average value of pigment increase or decrease for each aquarium containing holothurians.

During each of these experiments the faeces produced by holothurians in each aquarium were collected over two $24 \mathrm{~h}$ periods and their dry weights were determined. The average of this value was divided by the area of the aquarium $\left(0.116 \mathrm{~m}^{2}\right.$ when holothurians had access to half of the aquarium, $0.232 \mathrm{~m}^{2}$ when the whole area was grazed) to provide an estimate for the bioturbation per $\mathrm{m}^{2}$ simulated in each container. The relation between the latter parameter and the daily decrease in pigment concentrations was analysed with a linear regression model.

\section{RESULTS}

\section{Expt A-effect of exposure time}

Production in enhanced conditions was significantly higher than in controls from $4.5 \mathrm{~h}$ of exposure onwards (Fig. 1 ; a posteriori nonparametric sign test for all 10 observations $>3 \mathrm{~h}: \mathrm{p}=0.002$ ).

Water-column ammonium concentrations of both the inflowing water and the water in the treatment aquaria were distinctly enhanced in all 3 experiments (Table 1). In Expt A3, the concentrations of all macronutrient species were determined. These measurements indicate that only ammonium is measurably enhanced in the water inside the aquaria. Measurements of the inflowing water of both the control and the treatment aquaria showed that this water had higher levels of ammonium and several other nutrient species than the actual aquarium water (Table 1). This may indicate that nutrients are rapidly taken up by the benthic microflora, resulting in reduced nutrient levels in the actual aquarium water. 


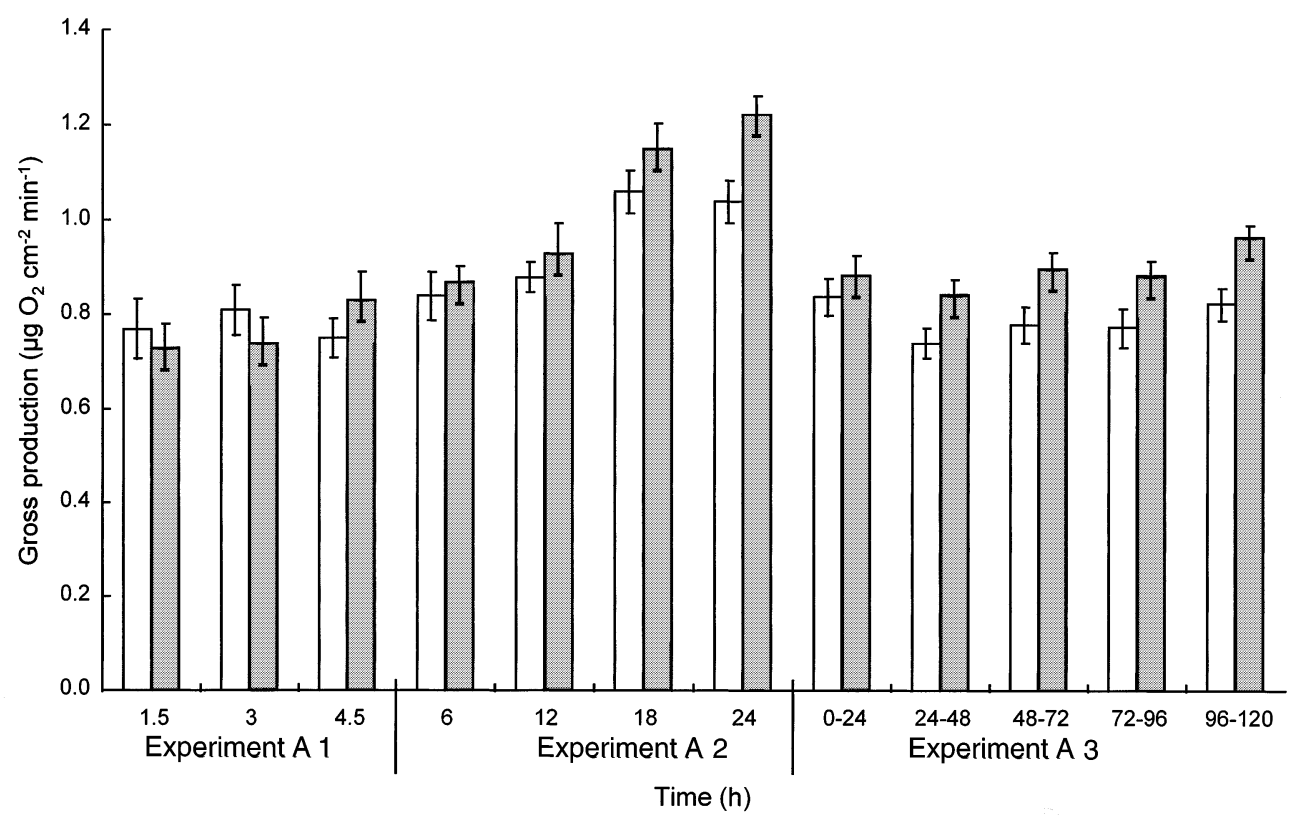

Fig. 1. Expts A1 to 3. Effect of exposure time to nutrients regenerated by holothurians on benthic microalgal community production. Grey bars: treatments receiving effluent water from tanks containing holothurians Stichopus chloronotus and Holothuria atra. White bars: unfertilised controls; error bars $= \pm 1 \mathrm{SE}$

\section{Expt B - enhancement with direct addition of phosphate and ammonium}

Nutrient enhancement with solutions of either or both phosphate and ammonium led to significant differences in community gross production between the 4 treatments (ANOVA, MS $=0.1122, F=5.38, \mathrm{p}=0.0037$, Fig. 2). Post hoc comparison of means (Tukey's HSD

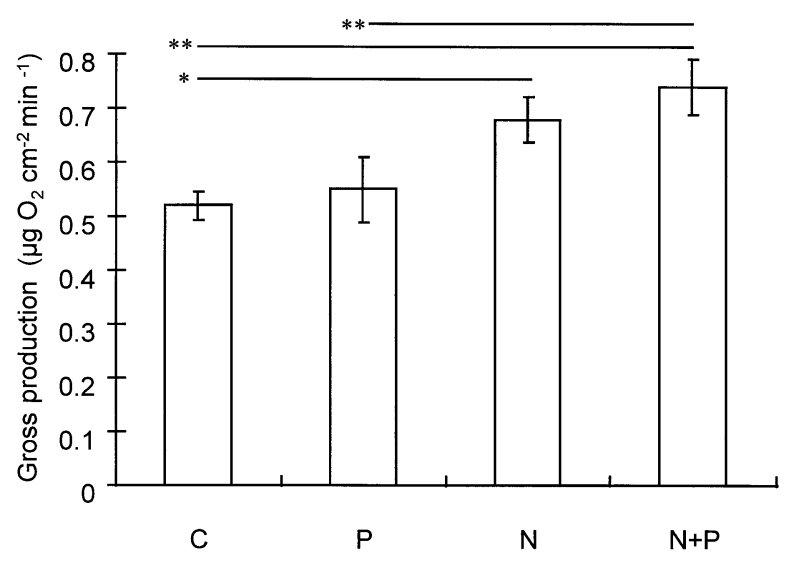

Fig. 2. Expt B. Benthic community production in unfertilised controls $(\mathrm{C})$, with phosphate addition $(\mathrm{P})$, ammonium addition $(\mathrm{N})$ and addition of both nutrients $(\mathrm{N}+\mathrm{P})$. Error bars $= \pm 1 \mathrm{SE}$; horizontal lines connect groups which are significantly different (post hoc comparison: Tukey's HSD test). Significance levels: ${ }^{*} 0.1>\mathrm{p}>0.05,{ }^{* *} 0.01<\mathrm{p}<0.05$ test) revealed that the phosphate treatment was not significantly different from the control $(p=0.9578)$, but both the N+P (p=0.0072) treatment and the $\mathrm{N}(\mathrm{p}=$ 0.0772 ) treatment resulted in a significant production enhancement, although this effect was only marginally significant with the addition of $\mathrm{N}$ only. Thus, the enhancement effect is most distinct with the addition of both nutrients, although addition of phosphate alone had no effect. Nutrient analyses in the treatment waters confirmed that the nutrient concentrations attained the attempted concentrations (Table 2).

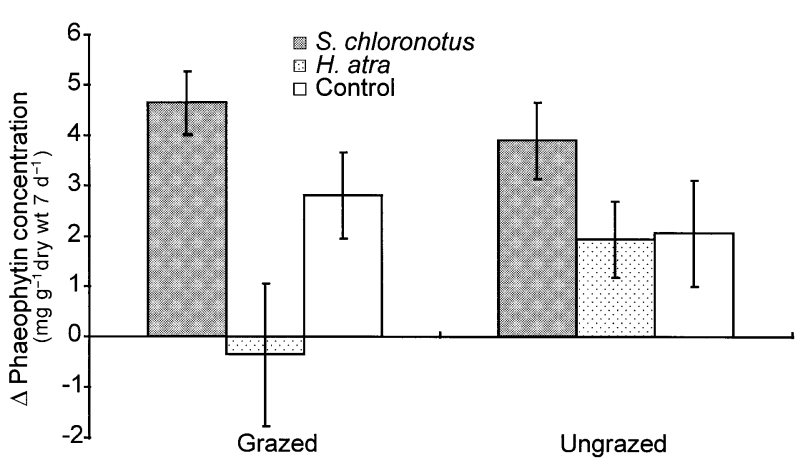

Fig. 3. Expt C. Phaeophytin increase (difference between end and start concentrations) of grazed and ungrazed sides in 3 different treatments (Stichopus chloronotus, Holothuria atra, control) (treatment $\times$ grazed interaction, Table 3). Error bars = $\pm 1 \mathrm{SE}$ 
Table 1. Expts A1, 2, 3. Water-column nutrient concentrations ( $\mu \mathrm{M}, \pm \mathrm{SD}$ ) in treatments and controls of time-course experiments on production enhancement. $\mathrm{NH}_{4}$ : ammonium, $\mathrm{NO}_{3}$ : nitrate, $\mathrm{NO}_{2}$ : nitrite, $\mathrm{PO}_{4}$ : phosphate, DON: dissolved organic nitrogen, DOP: dissolved organic phosphate, $n$ : number of replicates

\begin{tabular}{|c|c|c|c|c|c|c|c|c|}
\hline & \multirow{2}{*}{$\begin{array}{c}\mathrm{A} 1 \\
(\mathrm{n}=2) \\
\mathrm{NH}_{4}\end{array}$} & \multirow{2}{*}{$\begin{array}{c}\mathrm{A} 2 \\
(\mathrm{n}=5) \\
\mathrm{NH}_{4}\end{array}$} & \multicolumn{6}{|c|}{$\begin{array}{c}\text { A3 } \\
(n=6)\end{array}$} \\
\hline & & & $\mathrm{NH}_{4}$ & $\mathrm{NO}_{3}$ & $\mathrm{NO}_{2}$ & $\mathrm{PO}_{4}$ & DON & DOP \\
\hline \multicolumn{9}{|l|}{ Treatment } \\
\hline Inflowing water & 2.34 & $\begin{array}{c}2.03 \\
(0.27)\end{array}$ & $\begin{array}{c}2.30 \\
(0.55)\end{array}$ & $\begin{array}{c}1.05 \\
(0.30)\end{array}$ & $\begin{array}{c}0.32 \\
(0.07)\end{array}$ & $\begin{array}{c}0.12 \\
(0.04)\end{array}$ & $\begin{array}{c}6.62 \\
(1.35)\end{array}$ & $\begin{array}{c}0.26 \\
(0.10)\end{array}$ \\
\hline Aquarium & 1.89 & $\begin{array}{l}1.40 \\
(0.15)\end{array}$ & $\begin{array}{c}1.85 \\
(0.23)\end{array}$ & $\begin{array}{c}0.75 \\
(0.22)\end{array}$ & $\begin{array}{c}0.27 \\
(0.08)\end{array}$ & $\begin{array}{c}0.10 \\
(0.03)\end{array}$ & $\begin{array}{c}5.35 \\
(0.40)\end{array}$ & $\begin{array}{c}0.27 \\
(0.11)\end{array}$ \\
\hline \multicolumn{9}{|l|}{ Control } \\
\hline Inflowing water & 0.49 & $\begin{array}{c}0.54 \\
(0.14)\end{array}$ & $\begin{array}{c}0.63 \\
(0.23)\end{array}$ & $\begin{array}{c}1.21 \\
(0.05)\end{array}$ & $\begin{array}{c}0.37 \\
(0.01)\end{array}$ & $\begin{array}{c}0.15 \\
(0.03)\end{array}$ & $\begin{array}{c}4.07 \\
(2.44)\end{array}$ & $\begin{array}{c}0.20 \\
(0.07)\end{array}$ \\
\hline Aquarium & 0.33 & $\begin{array}{c}0.48 \\
(0.14)\end{array}$ & $\begin{array}{c}0.48 \\
(0.09)\end{array}$ & $\begin{array}{c}0.98 \\
(0.23)\end{array}$ & $\begin{array}{c}0.31 \\
(0.08)\end{array}$ & $\begin{array}{c}0.11 \\
(0.02)\end{array}$ & $\begin{array}{c}6.04 \\
(2.85)\end{array}$ & $\begin{array}{c}0.24 \\
(0.20)\end{array}$ \\
\hline
\end{tabular}

\section{Expt $\mathrm{C}$ - production and biomass of grazed and ungrazed microalgae}

No significant differences in chlorophyll a concentrations due to the presence or absence of holothurians were detected in the experiment with grazed and ungrazed sediment microalgae (Table 3 ). The only significant difference detected was between the 2 experimental runs, the average chlorophyll a contents increased in Run A $\left(+1.36 \mu \mathrm{g} \mathrm{g}^{-1}\right.$ dry wt $7 \mathrm{~d}^{-1}$, SE = $0.16)$ whereas chlorophyll a content decreased in Run B $\left(-1.57 \mu g^{-1}\right.$ dry wt $\left.7 \mathrm{~d}^{-1}, \mathrm{SE}=0.46\right)$. The phaeophytin concentration showed significant effects both in the factors treatment and run (Table 3). However, both factors also had marginally significant interactions with other factors. Examination of the interaction of treatment $\times$ grazed (Fig. 3) showed that the increase in phaeophytin concentrations was slightly less in the ungrazed sides in Stichopus chloronotus and control aquaria compared to the grazed sides. In contrast, the phaeophytin concentrations decreased in sediments of the grazed sides of aquaria containing Holothuria atra. This decrease thus could be directly related to the

Table 2. Expt B. Nutrient concentrations $(\mu \mathrm{M}, \pm \mathrm{SD})$ in waters of the 4 different treatments during enhancement experiment with addition of phosphate and ammonium; number of samples $=8$

\begin{tabular}{|lcc|}
\hline Treatment & $\mathrm{PO}_{4}$ & $\mathrm{NH}_{4}$ \\
\hline Control & $0.13(0.02)$ & $0.06(0.03)$ \\
$+\mathrm{PO}_{4}$ & $0.31(0.01)$ & $0.05(0.04)$ \\
$+\mathrm{NH}_{4}$ & $0.12(0.02)$ & $1.80(0.16)$ \\
$+\mathrm{NH}_{4}+\mathrm{PO}_{4}$ & $0.32(0.03)$ & $1.75(0.16)$ \\
\hline
\end{tabular}

Table 3. Expt C. ANOVA of pigment analyses (chlorophyll $a$ and phaeophytin) and production rates of microalgae in aquaria experiments on effect of grazing by holothurians. Factors = treatment (3 levels: Stichopus chloronotus, Holothuria atra, control), grazing ( 2 levels, grazed vs ungrazed side), run ( 2 levels) and aquarium (nested in treatment). Dependent variables $=$ difference in sediment pigment contents $\left(\mu \mathrm{g}^{-1}\right.$ dry wt) or production $\left(\mu \mathrm{g} \mathrm{O}_{2} \mathrm{~cm}^{-2} \mathrm{~min}^{-1}\right)$ between the start and the end of the experimental run. Pigment data were log-transformed and production data were not transformed. Error terms = aquarium nested in treatment for treatment and the residual for all other terms (see 'Methods' for pooling procedures)

\begin{tabular}{|c|c|c|c|c|c|c|c|c|c|c|}
\hline \multirow{2}{*}{$\begin{array}{l}\text { Source of } \\
\text { variation }\end{array}$} & \multirow[t]{2}{*}{ df } & \multicolumn{3}{|c|}{ Chlorophyll a } & \multicolumn{3}{|c|}{ Phaeophytin } & \multicolumn{3}{|c|}{ Production } \\
\hline & & MS & $F$ & $\mathrm{p}$ & MS & $F$ & $\mathrm{p}$ & MS & $F$ & $\mathrm{p}$ \\
\hline Treatment $(\mathrm{T})$ & 2 & 0.00067 & 0.10 & 0.9102 & 0.03488 & 81.32 & 0.0024 & 0.0729 & 11.12 & 0.0410 \\
\hline Aquarium (T) & 3 & 0.00686 & 1.17 & 0.3752 & 0.00042 & 0.11 & 0.9499 & 0.00656 & 0.54 & 0.6668 \\
\hline Grazing (G) & 1 & 0.00019 & 0.03 & 0.8603 & 0.00186 & 0.49 & 0.5009 & 0.00835 & 0.70 & 0.4260 \\
\hline Run (R) & 1 & 0.11121 & 18.91 & 0.0019 & 0.02097 & 5.56 & 0.0428 & 0.06928 & 5.77 & 0.0397 \\
\hline $\mathrm{T} \times \mathrm{G}$ & 2 & 0.00083 & 0.14 & 0.8707 & 0.01142 & 3.02 & 0.0987 & 0.00118 & 0.10 & 0.9073 \\
\hline $\mathrm{T} \times \mathrm{R}$ & 2 & 0.00033 & 0.06 & 0.9465 & 0.01532 & 4.06 & 0.0553 & 0.00314 & 0.26 & 0.7753 \\
\hline $\mathrm{G} \times \mathrm{R}$ & 1 & 0.00124 & 0.21 & 0.6575 & 0.00162 & 0.43 & 0.5293 & 0.01002 & 0.83 & 0.3848 \\
\hline $\mathrm{T} \times \mathrm{G} \times \mathrm{R}$ & 2 & 0.00104 & 0.18 & 0.8410 & 0.00281 & 0.74 & 0.5023 & 0.01656 & 1.38 & 0.3002 \\
\hline Residual & 9 & 0.00588 & - & - & 0.00377 & - & - & 0.01201 & - & - \\
\hline
\end{tabular}


grazing activity of the latter species and did not occur on the ungrazed sides of the aquaria.

A plot of the interaction between the factors treatment $\times$ run (Fig. 4) showed that the phaeophytin concentration in the first run was only slightly reduced in aquaria containing Holothuria atra, whereas this decrease was much more distinct in the second run.

Community gross production showed significant changes caused by the factor treatment (Table 3). A post hoc comparison of means revealed that production was significantly enhanced in aquaria containing Holothuria atra $(\mathrm{p}=0.046)$; the enhancement was marginally significant in aquaria with Stichopus chloronotus ( $\mathrm{p}=0.064$, Fig. 5). This enhancement was independent of the factor grazed, which indicates that the production enhancement is a nutrient effect rather than a grazing effect, since it occurred in both sides of the aquaria containing holothurians. Significant differences in microbenthos production were also detected between the experimental runs (Table 3). Ammonium concentrations were distinctly enhanced in both exper-

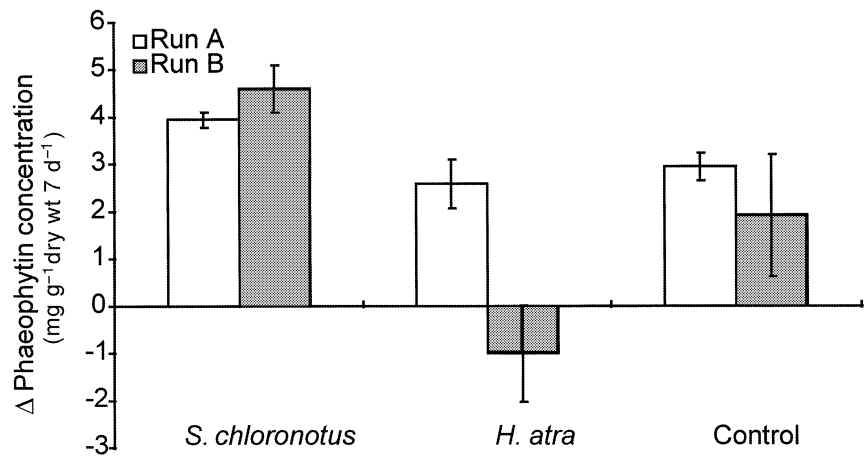

Fig. 4. Expt C. Phaeophytin increase (difference between end and start concentrations) in 3 different treatments (Stichopus chloronotus, Holothuria atra, control) in 2 experimental runs

(treatment $\times$ run interaction, Table 3 ). Error bars $= \pm 1 \mathrm{SE}$

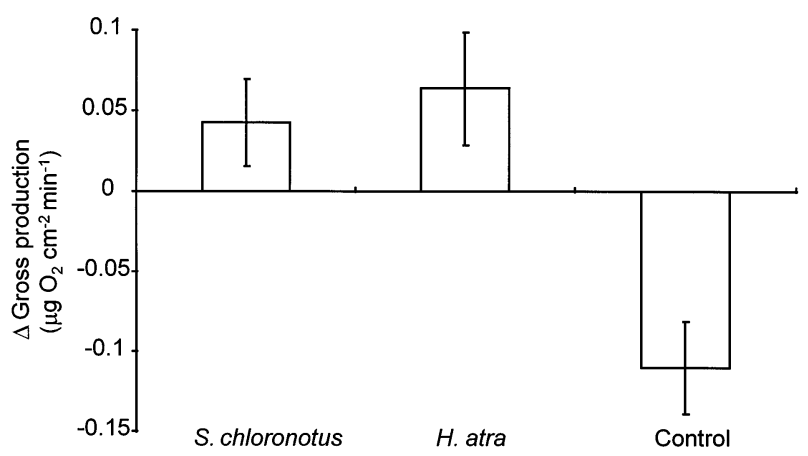

Fig. 5. Expt C. Microalgal community production increase (difference between end and start production) in 3 different treatments (Stichopus chloronotus, Holothuria atra, control) (factor treatment, Table 3). Error bars $= \pm 1 \mathrm{SE}$
Table 4. Expt C. Ammonium concentrations $(\mu \mathrm{M}, \pm \mathrm{SD})$ in 3 treatments in the 2 runs. Number of samples $=4$

\begin{tabular}{|lcc|}
\hline & & $\mathrm{NH}_{4}$ \\
& Run 1 & Run 2 \\
\hline Control & $0.25(0.07)$ & $0.12(0.13)$ \\
Stichopus chloronotus & $1.15(0.49)$ & $1.28(0.41)$ \\
Holothuria atra & $0.78(0.30)$ & $0.74(0.14)$ \\
\hline
\end{tabular}

imental runs in aquaria containing holothurians compared to control aquaria, with highest values occurring in aquaria containing $S$. chloronotus (Table 4 ).

\section{Expt D-time-course of microalgal biomass changes under grazed and ungrazed conditions}

Repeated-measures ANOVA indicated significant effects of the different treatments for chlorophyll $a$ but not for phaeophytin (Table 5). In the case of chlorophyll $a$, overall values were slightly higher on the grazed side $\left(3.58 \mu \mathrm{g} \mathrm{g}^{-1}\right.$ dry $\left.w \mathrm{t}, \mathrm{SE}=0.11\right)$ than on the ungrazed side $\left(3.17 \mathrm{\mu g} \mathrm{g}^{-1}\right.$ dry wt, $\left.\mathrm{SE}=0.11\right)$. However, the treatment $\times$ grazed interaction was not significant in this experiment, which indicated, that the bioturbation activity, even in the Holothuria atra treatment, was not high enough to reduce pigment levels; holothurian densities in this experiment were only half of that for Expt C. A distinct increase in chlorophyll a concentrations only in the Stichopus chloronotus treatment caused the significant interaction between time and treatment (Fig. 6). Although this interaction term was not significant for the phaeophytin concentrations, the val-

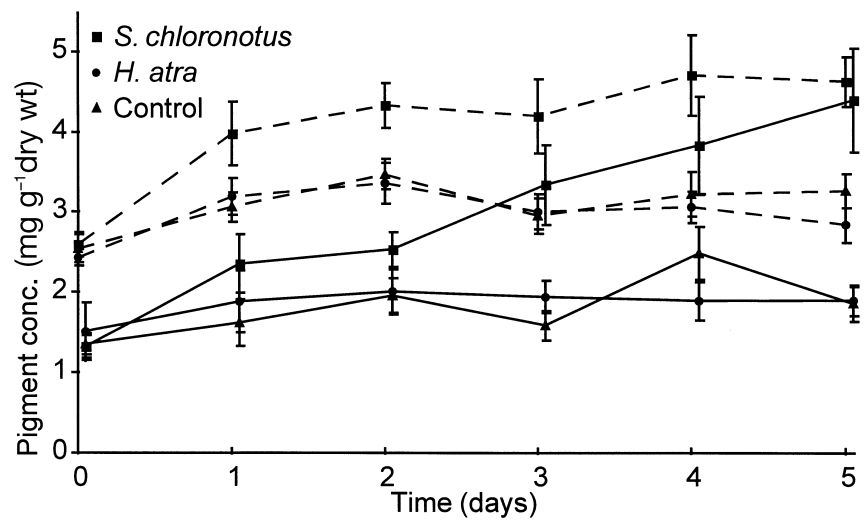

Fig. 6. Expt D. Concentrations of chlorophyll a (dashed line) and phaeophytin (continuous line) in sediments of the timecourse experiment on microalgal biomass changes in 3 different treatment conditions (Stichopus chloronotus, Holothuria atra, control). Error bars $= \pm 1 \mathrm{SE}$ 
Table 5. Expt D. Repeated-measures ANOVA of time-course experiments on changes (difference between end and start concentrations) in pigment concentrations ( $\mu \mathrm{g} \mathrm{g}^{-1}$ dry wt) in 3 treatments (factor treatment, levels = Stichopus chloronotus, Holothuria atra, control) and on grazed and ungrazed sides of aquaria (factor = grazed). Single replicate aquaria represent a nested factor (aquaria, nested in treatment). Measurements were repeated on 6 subsequent days. Data are log-transformed

\begin{tabular}{|c|c|c|c|c|c|c|c|c|}
\hline \multirow{2}{*}{$\begin{array}{l}\text { Source of } \\
\text { variation }\end{array}$} & \multirow[t]{2}{*}{$\mathrm{df}$} & \multirow{2}{*}{$\begin{array}{l}\text { Error } \\
\text { term }\end{array}$} & \multicolumn{3}{|c|}{ Chlorophyll a } & \multicolumn{3}{|c|}{ Phaeophytin } \\
\hline & & & MS & $F$ & $\mathrm{p}$ & MS & $F$ & $\mathrm{p}$ \\
\hline \multicolumn{9}{|l|}{ Between subjects } \\
\hline Treatment (Tr) & 2 & $\mathrm{~A}(\mathrm{Tr})$ & 0.2023 & 9.53 & 0.0502 & 0.3938 & 5.26 & 0.1029 \\
\hline Aquarium (Tr) & 3 & Residual & 0.0212 & 2.52 & 0.0812 & 0.0748 & 4.19 & 0.0161 \\
\hline Grazed (G) & 1 & $\mathrm{~A}(\mathrm{Tr}) \times \mathrm{G}$ & 0.0897 & 5.47 & 0.0998 & 0.0440 & 0.35 & 0.5957 \\
\hline $\operatorname{Tr} \times \mathrm{G}$ & 2 & $\mathrm{~A}(\mathrm{Tr}) \times \mathrm{G}$ & 0.0048 & 0.23 & 0.8074 & 0.0108 & 0.09 & 0.9163 \\
\hline $\mathrm{A}(\mathrm{Tr}) \times \mathrm{G}$ & 3 & Residual & 0.0212 & 2.52 & 0.0812 & 0.1268 & 7.10 & 0.0010 \\
\hline Residual & 24 & & 0.0080 & - & - & 0.0179 & - & - \\
\hline \multicolumn{9}{|l|}{ Within subjects } \\
\hline Time (Ti) & 5 & $\mathrm{Ti} \times \mathrm{A}(\mathrm{Tr})$ & 0.0691 & 25.95 & $<0.0001$ & 0.1560 & 6.04 & 0.0030 \\
\hline $\mathrm{Ti} \times \operatorname{Tr}$ & 10 & $\mathrm{Ti} \times \mathrm{A}(\mathrm{Tr})$ & 0.0102 & 3.89 & 0.0091 & 0.0408 & 1.58 & 0.2050 \\
\hline $\mathrm{Ti} \times \mathrm{A}(\mathrm{Tr})$ & 15 & Residual & 0.0027 & 0.40 & 0.9761 & 0.0258 & 1.98 & 0.0217 \\
\hline $\mathrm{Ti} \times \mathrm{G}$ & 5 & $\mathrm{Ti} \times \mathrm{G} \times \mathrm{A}(\mathrm{Tr})$ & 0.0083 & 0.88 & 0.5208 & 0.0158 & 1.12 & 0.3914 \\
\hline $\mathrm{Ti} \times \operatorname{Tr} \times \mathrm{G}$ & 10 & $\mathrm{Ti} \times \mathrm{G} \times \mathrm{A}(\mathrm{Tr})$ & 0.0066 & 0.68 & 0.7292 & 0.0167 & 1.18 & 0.3740 \\
\hline $\mathrm{Ti} \times \mathrm{G} \times \mathrm{A}(\mathrm{Tr})$ & 15 & Residual & 0.0097 & 1.46 & 0.1381 & 0.0141 & 1.08 & 0.3792 \\
\hline Residual & 120 & & 0.0066 & - & - & 0.0130 & - & - \\
\hline
\end{tabular}

ues in the $S$. chloronotus treatment were distinctly above those in the $H$. atra aquaria and the controls, at least during the last $3 \mathrm{~d}$ of the experiment (Fig. 6).

Water-column ammonium analyses (Table 6) showed that the levels were distinctly enhanced in Stichopus chloronotus aquaria, and only slightly above the control level in aquaria containing Holothuria atra. All ammonium values were lower in the aquaria containing ungrazed microalgae, indicating that a fraction of the nutrients was already taken up by the microalgae in the aquaria containing holothurians. This may explain why the chlorophyll a levels were lower in the ungrazed treatments (see above).

\section{Expt E-additional experiments on algal biomass changes}

To gain further information about the interaction between grazing intensity and pigment increase or decrease, the pigment data from single aquaria of Expts $\mathrm{C}$ to $\mathrm{E}$ were subjected to a regression analyses with the inferred bioturbation rate per aquarium as independent variable. When analysed alone, both chlorophyll a $\left(\mathrm{R}^{2}=0.11, F_{1,36}=4.30, \mathrm{p}=0.0453\right)$ and phaeophytin $\left(\mathrm{R}^{2}=0.15, F_{1,36}=6.56, \mathrm{p}=0.0148\right)$ showed only very weak relationships with the bioturbation rate, both with a negative slope. When data from both pigments are pooled, a significant part of the variation $\left(\mathrm{R}^{2}=0.36, F_{1,36}=20.40, \mathrm{p}=0.001\right)$ in pigment concentrations may be explained by the extent of the bioturbation activity (Fig. 7). Although a large part of the variation remains unexplained, it is obvious that low
Table 6. Expt D. Ammonium concentrations $(\mu \mathrm{M}, \pm \mathrm{SD})$ in grazed and ungrazed aquaria of time-course experiment on the development of microalgal biomass. Number of samples $=8$

\begin{tabular}{|lcc|}
\hline & Grazed & $\mathrm{NH}_{4}$ \\
& & Ungrazed \\
\hline Control & $0.34(0.22)$ & $0.22(0.18)$ \\
Stichopus chloronotus & $1.54(0.37)$ & $0.89(0.26)$ \\
Holothuria atra & $0.62(0.40)$ & $0.45(0.55)$ \\
Inflowing water & $0.46(0.20)$ & \\
\hline
\end{tabular}

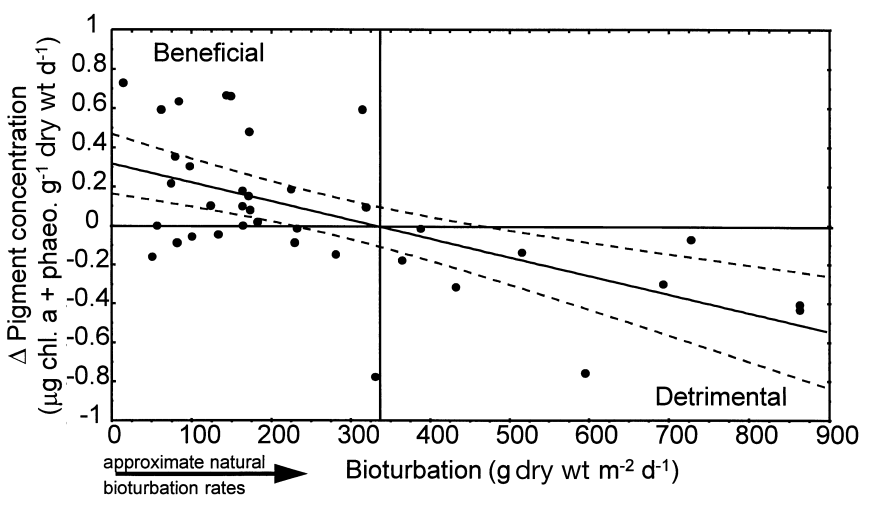

Fig. 7. Summary of Expts C to E. Data represent daily changes in pigment (chlorophyll $a$ and phaeophytin) concentrations relative to sediments in control aquaria in relation to sediment consumption (bioturbation) of holothurians in single aquaria. Approximate natural range of bioturbation rates is indicated and was calculated from density estimates (Uthicke unpubl. data) and known rates of sediment consumption for Holothuria atra and Stichopus chloronotus (Uthicke 1994) 
grazing intensities are beneficial for the algal community, whereas high bioturbation rates decrease total pigment content in the sediment. From the holothurian densities I obtained on the GBR (Uthicke 1994) and data on sediment consumption of Stichopus chloronotus and Holothuria atra (Uthicke 1999), I calculated the likely range of bioturbation intensity occurring in the field (Fig. 7). Notably, the bioturbation rates occurring in situ were all in a range low enough to be nondestructive and were thus likely to be beneficial for the algal community.

\section{DISCUSSION}

\section{Positive feedback effects: microalgal community production enhancement by holothurian excretion products}

An efficient recycling through a close coupling of producers and consumers of inorganic nutrients generally is assumed to be important in maintaining high productivity on coral reefs and other ecosystems in oligotrophic environments. Microalgae on sediments are important primary producers on coral reefs, but their role in the flow of energy and materials in this ecosystem is poorly understood. Benthic microalgae are consumed by sediment-feeders, and I aimed to investigate whether nutrients also are efficiently recycled between these 2 trophic groups.

Previous studies reported that waste products from the holothurians metabolism lead to a $34 \%$ enhancement in gross and net production of the microalgal community in aquaria (Uthicke \& Klumpp 1997) and in situ (Uthicke \& Klumpp 1998). In the experiments described here, the use of effluent water from holothurian tanks distinctly elevated the ammonium concentrations compared to the control aquaria. No increase in phosphate or dissolved organic phosphate concentrations was measured, although a release of small amounts of phosphate by holothurians was previously reported (Pomeroy \& Kuenzler 1969, Webb et al. 1977). It is likely that the low amount of phosphate was chemically adsorbed to calcium carbonate (Entsch et al. 1983) and/or taken up by the microalgal community, and was thus not detectable.

In the time-series experiments (Expts A1 to A3), an enhanced community production was measured for exposure times longer than $3 \mathrm{~h}$ (Fig. 1). Thus, the production of benthic microalgae rapidly increased in response to higher nutrient availability.

The direct enhancement of benthic microalgal communities with phosphate and ammonium (Expt B) suggested that the stimulation effect observed in the experiments using the excretion products of holothuri- ans was mainly caused by the excretion of inorganic $\mathrm{N}$, and not by some unknown compound (e.g. micronutrients) released by the holothurians. The highest production values were observed with simultaneous addition of phosphate and ammonium (Fig. 2). It is therefore likely, that both phosphate and ammonium (as excretion products) interact in the enhancement of microalgal production. Not all nutrients excreted by holothurians may reach the sediment algal community. However, several mechanisms such as nutrient release with the respiratory water in the vicinity of the sediments and via the bodywall that is partly in direct physical contact with the sediments (approximately $25 \%$ : Uthicke unpubl. data) may result in a fraction of the nutrients recycled by holothurians being available for the production of new microalgal biomass. Furthermore it is likely that nutrients excreted by sedimentfeeders are retained close to the sediment in a benthic boundary layer.

There are no published data on the nutrient supply of microphytobenthos on coral reefs, but some temperate benthic microalgae have been suggested to be nutrient-limited (Mills \& Wilkinson 1986). The low photosynthetic efficiencies measured in situ also suggested a nutrient limitation of the microalgal community at Great Palm Island (Uthicke \& Klumpp 1998). The addition of $\mathrm{N}$ and $\mathrm{P}$ in combination to a microatoll on a coral reef in the GBR enhanced the overall productivity of that microatoll (Kinsey \& Domm 1974). An addition of $\mathrm{N}$ only to microatolls may increase the biomass or growth of turf algae (Hatcher \& Larkum 1983). The limiting nutrients for macrophyte production on coral reefs may be either $\mathrm{N}, \mathrm{P}$ or both nutrients combined (Lapointe et al. 1987, Littler et al. 1991).

Similar to my observations on microalgae, the growth of the brown alga Sargassum baccularia at nearshore reefs of the GBR is limited by both $\mathrm{N}$ and $\mathrm{P}$ (Schaffelke \& Klumpp 1998). However, I expected nutrient limitation of benthic microalgae to be less pronounced than that of macroalgae, since microalgae may have access to nutrients in the interstitial water which are generally much higher concentrated. The uptake of nutrients diffused from the interstitial water was previously suggested for temperate (Sundbäck \& Granéli 1988) and tropical (Johnstone et al. 1989) microalgal communities. Hence, the distinct reaction of the microalgal communities to slightly enhanced nutrients is not fully understood and requires further investigation.

Nutrient fluxes between marine fauna and photoautotrophic organisms rarely have been studied on coral reefs. Ammonium excretion of the echinoid Diadema antillarum may potentially provide $19 \%$ of the $\mathrm{N}$ demand of algal turfs (Williams \& Carpenter 1988). The growth of corals and their tissue-nutrient contents is enhanced by ammonium excretion of 
migrating fishes that use these corals as a shelter (Meyer et al. 1983, Meyer \& Schultz 1985). It is known that inorganic nutrients are recycled efficiently between zooxanthellate corals and their endosymbionts, and most nutrients excreted by the corals are taken up by the zooxanthellae (e.g. Pomeroy \& Kuenzler 1969, Szmant et al. 1990).

Lindström-Swanberg (1991) subjected temperate sediment-microalgae to effluent water from tanks containing bivalves (Cerastoderma edule), and measured enhanced production in these treatments compared to controls. Similar to my study, he concluded that this enhancement was mainly due to ammonium released by the bivalves. Studies on planktonic microalgae revealed that these have extremely fast uptake rates of ammonium (Goldman \& Glibert 1982). It has been suggested that planktonic microalgae can use microscale (scale of $\mathrm{mm}$ ) patches of nutrients recycled by zooplankton (Goldman \& Glibert 1982, Lehman \& Scavia 1982). No nutrient uptake rates are available for benthic diatoms. If uptake rates were as rapid as those of the phytoplankton, the nutrients excreted by sediment-feeders may be used in a fashion similar to that suggested for the plankton micropatches. I calculated that the water released during the respiratory expulsions of 1 sea cucumber may enhance ammonium concentrations for a short period of time over an area of nearly $0.2 \mathrm{~m}^{2} \mathrm{~h}^{-1}$ (Uthicke unpubl. data). However, the slow movement rates of holothurians suggest that the sediment area covered by the water from the waterlungs will be somewhat smaller, but this smaller area will receive multiple excretion pulses. In conjunction with the feeding activity of Stichopus chloronotus, which may be highly selective for sediment patches rich in microalgal biomass (Uthicke 1999, Uthicke \& Karez 1999), the sporadic fertilisation of algae in small areas may contribute to the patchiness of microalgal biomass and production in coral reef sediments.

\section{Combined positive and negative feedback effects: production enhancement by excretion versus biomass loss through consumption}

The second hypothesis I tested in this study was that the presence of sediment-feeders is beneficial to benthic microalgae, although these are partially consumed. The enhancement experiments discussed above concentrated only on the positive effects of holothurians on microalgae through increased availability of nutrients. I performed additional experiments to investigate the losses of microalgal biomass due to grazing and to assess whether the net effect of holothurian activity for the microalgal biomass and production is positive or negative.
In Expt C, feeding intensity did not affect chlorophyll a concentrations in aquaria grazed by Holothuria atra or Stichopus chloronotus. In contrast, production of the microalgae was distinctly enhanced in aquaria containing holothurians, with no distinction between microalgae protected from grazing or those exposed to grazing (Fig. 5). Thus, the production of the microalgal community was enhanced, irrespective of physical contact with the holothurians (Expt C: grazed treatment, holothurians present; Expts A1, 2, 3 and Expt C: ungrazed treatment, holothurians absent).

Expt D used lower holothurian densities than Expt C, and no reduction of the pigments was measured. In fact, in all aquaria which either contained individuals of Stichopus chloronotus or received the ammoniumrich effluent water from these tanks, chlorophyll $a$ and phaeophytin concentrations increased compared to control aquaria and those containing Holothuria atra (Fig. 6). An increase in pigment concentrations was not measurable in Expt $C_{i}$ this underlines the fact that the outcome of the experiments was strongly dependent on the actual bioturbation intensity and probably other factors such as nutrient status of the algae prior to the experiment.

An estimate of the bioturbation intensity was obtained by collecting and weighing holothurian faeces from each single aquarium of the Expts C, D and E. The correlation between bioturbation intensity and the total pigment decrease (Fig. 7) provides evidence that pigment changes depend on bioturbation intensity. These data strongly support the hypothesis that holothurians in the densities observed in situ will not have a negative effect on the microbenthos and that the positive effects due to stimulation by excreted nutrients are likely to balance or exceed the losses due to grazing.

Two previous studies reported that grazing by holothurians may decrease benthic community production (Moriarty et al. 1985) and biomass (Uthicke 1999). Both studies used much higher densities than those found naturally, and thus the findings do not contradict the results of the present study. The consequences of consumption for the single algae are surely detrimental, because of the high assimilation efficiencies reported for diatoms in holothurians (Yingst 1976). However, the biomass loss due to holothurian grazing is outweighed by the enhanced availability of $\mathrm{P}$ and $\mathrm{N}$ that is re-mineralised by the holothurians.

In contrast to the sparse data on sediment communities, the direct effects of grazing fishes (e.g. Hatcher 1983, Hatcher \& Larkum 1983, Hay 1984, Hughes 1994), echinoids (e.g. Sammarco 1980, Carpenter 1983), and small grazers such as amphipods and isopods (Brawley \& Adey 1981) on macroalgae have been well studied on coral reefs. The combined grazing activity of echinoids, amphipods, isopods and fishes may re- 
move up to $84 \%$ of the daily production of turf-algae biomass on coral reefs (Carpenter 1983, Klumpp \& Polunin 1990). The removal of turf-algae biomass may be beneficial for coral growth in these areas, and although coral recruitment may be higher in ungrazed areas (Sammarco 1980), the survival rate of coral recruits is higher in areas grazed by echinoids (Sammarco 1980, Fitz et al. 1983).

In summary, the production enhancement measured in the microbenthic community in several experiments in the present study appeared to be solely a nutrient effect and not caused by other factors such as a reduction of self-shading, removal of senescent cells, or the compensatory growth that was hypothesised for turf algae (Carpenter 1986) and for terrestrial grasses (McNaughton 1979, 1983). For the microphytobenthos community studied, which was predominantly composed of unicellular organisms such as pennate diatoms, concepts such as self-shading or compensatory growth are meaningless because entire organisms are consumed. However, algae not consumed may benefit from enhanced light conditions if the algae are situated on the sediment in multiple layers. In freshwater plankton, the growth rates of a variety of unicellular algae were enhanced when in contact with excretion products of grazing zooplankton (Porter 1976, Sterner 1986). Related to the whole phytoplankton community, the indirect effect of production enhancement approximately compensated for the direct effect of the loss of cells by grazing (Sterner 1986), and this situation may be similar in marine benthic microalgal communities.

High numbers of heterotrophic flagellates, ciliates and meiofauna in coral reef sediments (Alongi 1986, Hansen et al. 1987) and the large difference between gross and net-production of the sediment community at the study area (Uthicke \& Klumpp 1998) suggest that a substantial fraction of the organic carbon produced by the microalgae is directly recycled by heterotrophic infauna. This indicates that nutrients are indeed tightly recycled within the benthic system. Meiofauna excretion rates in coral reef sediments may be as high as $17.3 \mathrm{mg} \mathrm{N} \mathrm{m}{ }^{-2} \mathrm{~h}^{-1}$ (Gray 1985). The interactions between sediment-feeders, benthic infauna and benthic microalgae are a further example of the closecoupling between producers and consumers in nutrient-poor environments. It is likely that the bulk of the nutrients required by the benthic microalgae is recycled within a benthic remineralisation system with some similarity to the planktonic microbial loop (Azam et al. 1983).

One assumption of the planktonic microbial loop is that consumers generally prey upon food approximately 1 order of magnitude smaller than themselves (Azam et al. 1983, Lenz 1992). In contrast, holothurians and other sediment-feeders feed on material and organisms spanning 3 orders of magnitude (approximately from bacteria $<1 \mu \mathrm{m}$ up to diatoms $>1 \mathrm{~mm}$ ), and thus their function in such a food web is very difficult to grasp. Generally, grazing on a microbial food source in the benthos may increase productivity by preventing bacteria from reaching self-limiting densities (Johannes 1965, Gerlach 1978, Montagna 1984). A similar mechanism was suggested for gastropod grazing on bacteria in temperate (Bianchi \& Levington 1981, 1984) and coral reef sediments (Hansen \& Skilleter 1994), and the feeding activity of detritivores may stimulate bacterial decomposition of detritus (Fenchel 1971, Kristensen et al. 1992). Holothurians and meiofauna may compete for bacteria as food (Renaud-Mornant \& Helléouet 1977, Moriarty 1982). A variety of further interactions such as competition between ciliates and sedimentfeeders for diatoms as a food source, or between sediment-feeders and bacteria (although the latter are also a food source of the former) for non-living organic matter may exist. Thus, sediment-feeding macro- and megafauna may interact directly with nearly every level of the suggested benthic remineralisation loop and, in addition to direct recycling of nutrients, may also increase the overall performance of this loop.

Acknowledgements. I thank B. Schaffelke for many fruitful discussions on the topic of this paper and for reviewing the manuscript. I am also indebted to D. McKinnon who was very patient in introducing me to the respirometer-technique. The manuscript greatly benefited from the comments of 4 anonymous referees. I am very grateful to D. Klumpp for the provision of laboratory space and the data-loggers. The work described in this paper was partially funded by a grant of the German DAAD. This is contribution number 1050 from the Australian Institute of Marine Science.

\section{LITERATURE CITED}

Alongi DM (1986) Quantitative estimates of benthic protozoa in tropical marine systems using silicia gel: a comparison of methods. Estuar Coast Shelf Sci 23:443-450

Arias-Gonzáles JE, Delesalle B, Salvat B, Galzin R (1997) Trophic functioning of the Tiahura reef sector, Moorea Island, French Polynesia. Coral Reefs 16:231-246

Atkinson MJ (1989) Are coral reefs nutrient limited? In: Choat JH et al. (eds) Proc 6th Int Coral Reef Symp, Vol 1. Executive Committee, Townsville, p 157-166

Azam F, Fenchel T, Field JG, Gray JS, Meyer-Reil LA, Thingstad F (1983) The ecological role of water-column microbes in the sea. Mar Ecol Prog Ser 10:257-263

Bianchi TS, Levington JS (1981) Nutrition and food limitation of deposit feeders. 2. Differential effects of Hydrobia totteni and Ilyanassa obsoleta on the microbial community. J Mar Res 39:547-556

Bianchi TS, Levington JS (1984) The importance of microalgae, bacteria and particulate organic matter in the somatic growth of Hydrobia totteni. J Mar Res 42:431-443

Brawley SH, Adey WH (1981) The effect of micrograzers on 
coral community structure in a coral reef microcosm. Mar Biol 61:167-177

Carpenter RC (1983) Differential effects of coral reef herbivores on algal community structure and function. NOAA Symp Ser Undersea Res 1:113-118

Carpenter RC (1986) Partitioning herbivory and its effects on coral reef algal communities. Ecol Monogr 56:345-363

Crossland CJ, Hatcher BG, Atkinson MJ, Smith SV (1984) Dissolved nutrients of a high-latitude coral reef, Houtman Abrolhos Islands, Western Australia. Mar Ecol Prog Ser 14:159-163

D'Elia CF, Wiebe WJ (1990) Biogeochemical nutrient cycles in coral reef ecosystems. In: Dubinsky Z (ed) Ecosystems of the world, Vol 25. Coral reefs. Elsevier, Amsterdam, p 49-74

Entsch B, Boto KG, Sim RG, Wellington JT (1983) Phosphorus and nitrogen in coral reef sediments. Limnol Oceanogr 28: 465-476

Fenchel $\mathrm{T}$ (1971) Aspects of decomposer food chains in marine benthos. Verh Dt Zool Ges 65:14-23

Fitz HC, Reaka ML, Bermingham E, Wolf NG (1983) Coral recruitment at moderate depth: the influence of grazing. NOAA Symp Ser Undersea Res 1:89-96

Furnas MJ, Mitchell AW, Skuza M (1995) Nitrogen and phosphorus budgets for the Central Great Barrier Reef shelf. Great Barrier Reef Marine Park Authority, Townsville, Australia (Res Publ No 36)

Gerlach SA (1978) Food-chain relationships in subtidal silty sand marine sediments and the role of meiofauna in stimulating bacterial productivity. Oecologia 33:55-69

Glibert PM, Dennett MR, Caron DA (1988) Nitrogen uptake and $\mathrm{NH}_{4}+$ regeneration by pelagic microplankton and marine snow from the North Atlantic. J Mar Res 46: 837-852

Goldman JC, Glibert PM (1982) Comparative rapid ammonium uptake by four species of marine phytoplankton. Limnol Oceanogr 27:814-824

Gray JS (1985) Nitrogenous excretion by meiofauna from coral reef sediments. Mar Biol 89:31-35

Hansen JA, Skilleter GA (1994) Effects of the gastropod Rhinoclavis aspera (Linnaeus, 1758) on microbial biomass and productivity in coral reef sediments. Aust J Mar Freshw Res 45:569-584

Hansen JA, Alongi DM, Moriarty DJW, Pollard PC (1987) The dynamics of benthic microbial communities at Davies Reef, Central Great Barrier Reef. Coral Reefs 6:63-70

Hatcher BG (1983) Grazing in coral reef ecosystems. In: Barnes DJ (ed) Perspectives in coral reefs. The Australian Institute of Marine Science, Townsville, Australia, p 164-179

Hatcher BG, Larkum AWD (1983) An experimental analyses of factors controlling the standing crop of the epilithic algal community on a coral reef. J Exp Mar Biol Ecol 69: $61-84$

Hay M (1984) Patterns of fish and urchin grazing on Caribbean coral reefs: are previous results typical? Ecology 65: 446-454

Hughes TP (1994) Catastrophes, phase shifts, and large scale degradation of a Caribbean coral reef. Science 265: 1547-1551

Johannes RE (1965) Influence of marine protozoa on nutrient regeneration. Limnol Oceanogr 10:434-442

Johnson C, Klumpp D, Field J, Bradbury R (1995) Carbon flux on coral reefs: effect of large shifts in community structure. Mar Ecol Prog Ser 126:123-143

Johnstone RW, Koop K, Larkum AWD (1989) Fluxes of inorganic nitrogen between sediments and water in a coral reef lagoon. Proc Linn Soc NSW 110:219-227
Kinsey DW, Domm A (1974) Effects of fertilisation on a coral reef environment-primary production studies. In: Cameron AM et al. (eds) Proc 2nd Int Coral Reef Symp Vol 1. Great Barrier Reef Committee, Brisbane, p 49-66

Klumpp DW, Polunin NVC (1990) Algal production, grazers and habitat partitioning on a coral reef: positive correlation between grazing rate and food availability. In: Barnes M, Gibson RN (eds) Proc 24th Eur Mar Biol Symp, Vol 1. University of Aberdeen Press, Aberdeen, p 372-388

Klumpp DW, McKinnon D, Daniel P (1987) Damselfish territories: zones of high productivity on coral reefs. Mar Ecol Prog Ser 40:40-51

Koroleff F (1983a) Determination of ammonia. In: Grasshoff K, Ehrhard M, Kremling K (eds) Methods of seawater analysis, Verlag Chemie, Weinheim, p 126-133

Koroleff F (1983b) Determination of phosphorus, In: Grasshoff $\mathrm{K}$, Ehrhard M, Kremling $\mathrm{K}$ (eds) Methods of seawater analysis. Verlag Chemie, Weinheim, p 117-126

Kristensen E, Ostergaard Andersen F, Blackburn TH (1992) Effects of benthic macrofauna and temperature on degradation of macroalgal detritus: the fate of organic carbon. Limnol Oceanogr 37:1404-1419

Lapointe BE, Littler MM, Littler DS (1987) A comparison of nutrient-limited productivity in macroalgae from a Caribbean barrier reef and from mangrove ecosystems. Aquat Bot 28:243-255

Lehman JT, Scavia D (1982) Microscale patchiness of nutrients in plankton communities. Science 216:729-730

Lenz J (1992) Microbial loop, microbial food web and classical food chain: their significance in pelagic marine environments. Arch Hydrobiol Beih Ergebn Limnol 37:265-278

Lindström-Swanberg I (1991) The influence of the filter-feeding bivalve Cerastoderma edule L. on microphytobenthos: a laboratory study. J Exp Mar Biol Ecol 151:93-111

Littler MM, Littler DS (1984) Models of tropical reef biogenesis: the contribution of algae. In: Round FE, Chapman DJ (eds) Progress in phycological research, Vol 3. Biopress, Bristol, p 323-364

Littler MM, Littler DS, Titlyanov EA (1991) Comparisons of Nand P-limited productivity between high granite islands versus low carbonate atolls in the Seychelles Archipelago: a test of the relative dominance paradigm. Coral Reefs 10: 199-209

Massin C (1982) Food and feeding mechanism: Holothuroidea. In: Jangoux M, Lawrence JM (eds) Echinoderm nutrition. Balkema, Rotterdam, p 43-55

McNaughton SJ (1979) Grazing as an optimization process: grass-ungulate relationships in the Serengeti. Am Nat 113:691-703

McNaughton SJ (1983) Compensatory growth as a response to herbivory. Oikos 40:329-336

Meyer JL, Schulz ET (1985) Tissue condition and growth rates of corals associated with schooling fish. Limnol Oceanogr 30:157-166

Meyer JL, Schulz ET, Helfman GS (1983) Fish schools: an asset to coral reefs. Science 220:1047-1048

Milchunas DG, Lauenroth WK (1993) Quantitative effects of grazing on vegetation and soils over a global range of environments. Ecol Monogr 63:327-366

Miller CA, Penry DL, Glibert PM (1995) The impact of trophic interactions on rates of nitrogen regeneration and grazing in Chesapeake Bay. Limnol Oceanogr 40:1005-1011

Mills DK, Wilkinson M (1986) Photosynthesis and light in estuarine benthic microalgae. Bot Mar 14:125-129

Mitchell SF, Wass RT (1996) Quantifying herbivory: grazing consumption and interaction strength. Oikos 76:573-576

Montagna PA (1984) In situ measurement of meiobenthic 
grazing rates on marine sediment bacteria and edaphic diatoms. Mar Ecol Prog Ser 18:119-130

Moriarty DJW (1982) Feeding of Holothuria atra and Stichopus chloronotus on bacteria, organic carbon and organic nitrogen in sediments of the Great Barrier Reef. Aust J Mar Freshw Res 33:255-263

Moriarty DJW, Pollard PC, Hunt WG, Moriarty CM, Wassenberg TJ (1985) Productivity of bacteria and microalgae and the effect of grazing by holothurians in sediments on a coral reef flat. Mar Biol 85:293-300

Mukai H, Koike I, Nishihira M, Nojima S (1989) Oxygen consumption and ammonium excretion of mega-sized benthic invertebrates in a tropical seagrass bed. J Exp Mar Biol Ecol 134:101-115

Mulholland PJ, Steinman AD, Palumbo AV, Elwood JW (1991) Role of nutrient cycling and herbivory in regulating periphyton communities in laboratory streams. Ecology 72: 966-982

Newbold JD, O'Neill RV, Elwood JW, van Winkle W (1982) Nutrient spiralling in streams: implications for nutrient limitation and invertebrate activity. Am Nat 120:628-652

Pomeroy LR, Kuenzler EJ (1969) Phosphorus turnover by coral reef animals. In: Nelson DJ, Evans FC (eds) Symposium on radioecology. NTIS, Springfield, VA, p 474-482

Porter KG (1976) Enhancement of algal growth and productivity by grazing zooplankton. Science 192:1332-1334

Renaud-Mornant J, Helléouet MN (1977) Rapport micromeiobenthos et Halodeima atra (Holothuroidea) dans un lagon polynesién (Tiahura, Moorea, ils de la société). Bull Mus Natl Hist Nat, Paris 474:853-865

Ryle VD, Müller HR, Gentien P (1981) Automated analysis of nutrients in tropical seawater Australian Institute of Marine Science, Townsville, Australia (AIMS Oceanogr Ser AIMS-OS-82-2)

Sammarco PW (1980) Diadema and its relationship to spat mortality: grazing competition and biological disturbance. J Exp Mar Biol Ecol 45:245-272

Schaffelke B, Klumpp DW (1998) Nutrient-limited growth of the coral reef macroalga Sargassum baccularia and experimental growth enhancement by nutrient addition in continuous flow culture. Mar Ecol Prog Ser 164: $199-211$

Sorokin YI (1990) Aspects of trophic relations, productivity and energy balance in coral-reef ecosystems. In: Dubinsky Z (ed) Ecosystems of the world, Vol 25. Coral reefs. Elsevier, Amsterdam, p 401-410
Sorokin YI (1993) Coral reef ecology. Ecological studies. Springer-Verlag, New York

Statsoft (1994) Statistica for Windows. Volume I-III. Statsoft Inc, Tulsa, OK

Sterner RW (1986) Herbivores' direct and indirect effects on algal populations. Science 231:605-607

Sundbäck K, Granéli W (1988) Influence of microphytobenthos on the nutrient flux between sediment and waters: a laboratory study. Mar Ecol Prog Ser 43:63-69

Szmant AM, Ferrer LM, FitzGerald LM (1990) Nitrogen excretion and O:N ratios in coral reefs: evidence for conservation of nitrogen. Mar Biol 104:119-127

Uthicke S (1994) Distribution patterns and growth of two reef flat holothurians, Holothuria atra and Stichopus chloronotus. In: David B, Guille A, Féral JP, Roux M (eds) Echinoderms through time. Proc 8th Int Echinoderm Conf, Dijon Balkema, Rotterdam, p 569-576

Uthicke S (1999) Sediment bioturbation and impact of feeding activity of Holothuria (Halodeima) atra and Stichopus chloronotus, two sediment feeding holothurians, at Lizard Island, Great Barrier Reef. Bull Mar Sci 64:129-141

Uthicke S, Karez R (1999) Sediment patch selectivity in tropical sea cucumbers (Holothurioidea: Aspidochirotida) analysed with multiple choice experiments. J Exp Mar Biol Ecol 236:69-87

Uthicke S, Klumpp DW (1997) Ammonium excretion by holothurians enhances production and turnover in benthic diatom communities. In: Lessios HA, Macintyre IG (eds) Proc 8th Int Coral Reef Symp, Vol 1. Smithsonian Tropical Research Institute, Panamá, p 873-876

Uthicke S, Klumpp DW (1998) Microbenthos community production in sediments of a near shore coral reef: seasonal variation and response to ammonium recycled by holothurians. Mar Ecol Prog Ser 169:1-11

Webb KL, D'Elia CF, Dupaul WD (1977) Biomass and nutrition flux measurements on Holothuria atra populations on windward reef flats at Enewetak, Marshall Islands. In: Taylor DL (ed) Proc 3rd Int Coral Reef Symp, Vol 1. Rosenstiel School of Marine and Atmospheric Science, Miami, FL, p 410-415

Williams SL, Carpenter RC (1988) Nitrogen-limited primary productivity of coral reef algal turfs: potential contribution of ammonia excreted by Diadema antillarum. Mar Ecol Prog Ser 47:145-152

Yingst JY (1976) The utilization of organic matter in shallow marine sediments by an epibenthic deposit feeding holothurian. J Exp Mar Biol Ecol 23:55-69

Submitted: February 25, 2000; Accepted: June 27, 2000

Proofs received from author(s): January 2, 2001 